percevoir les rentes; c'est donc maintenant M. de Goeje et ce sera après sa mort le membre que le conseil désignera comme trésorier.

L'assentîment et le concours de tous les membres du conseil est requis pour vendre, en tout ou en partie, les capitaux inscrits au grand livre; d'autres formalités ne sont pas nécessaires.

ART. 7.-Il sera permis de déroger aux articles 4, 5, et 6, si, dans deux séances successives, le conseil déclare à l'unanimité des voix que les circonstances nécessitent un écart précisé d'avance.

Ajoutons que le capital de la fondation se monte actuellement à 19,500 florins hollandais (39,000 francs), et que $M$. de Goeje, quoique resté membre du conseil, a été remplacé comme président par M. Snouck Hurgronje et comme trésorier par le secrétaire du conseil $M$. van Vollenhoven.

\title{
Derivation of Dhamek or Dhamekh
}

In the Journal for 1908, p. 1156, Messrs. Hoey and Venis have pointed out that the old Jain form of the name Dhamek or Dhamekh, by which the great $s t \bar{u} p a$ of Sārnāth is known, was Dharmekșā, which may be rendered "pondering of the Law". Dr. Hoey further remarks that he does not remember any corresponding technical Buddhist expression. Perhaps the technical expression for which he is seeking may be found in dhammāpelh $\bar{a}$, which occurs in the first pillar edict of Asoka, bracketed with dhamma$k \bar{\alpha} m a t \bar{a}$. The two compounds are translated as "the longing for the sacred law and the love of the sacred law" by Bühler, and as "ce souci de la religion, le zéle pour la religion" by Senart. The $p$ of apelch $\bar{\alpha}$ (apekşa) might be elided without difficulty. Of course, apeks $\bar{\alpha}$ is only a slight

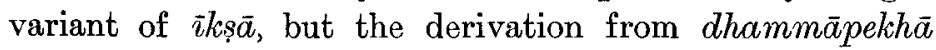
rather than from dharmekșa is so far preferable that dhammāpekha is known to occur as a Buddhist term.

Vincent A. SMith. 